\title{
Cellobiohydrolase B of Aspergillus niger over-expressed in Pichia pastoris stimulates hydrolysis of oil palm empty fruit bunches
}

\author{
James Sy-Keen Woon ${ }^{1,2}$ ， Mukram M Mackeen ${ }^{3,4}$ ， Rosli M Illias ${ }^{5}$ ， Nor M Mahadi ${ }^{4,6}$ ， William J Broughton ${ }^{7}$, \\ Abdul Munir Abdul Murad ${ }^{1}$, Farah Diba Abu Bakar ${ }^{\text {Corresp. } 1}$ \\ ${ }^{1}$ School of Biosciences and Biotechnology, Faculty of Science and Technology, Universiti Kebangsaan Malaysia, Bangi, Selangor, Malaysia \\ 2 Present address: Newcastle University Medicine Malaysia, Iskandar Puteri, Johor, Malaysia \\ 3 School of Chemical Sciences and Food Technology, Faculty of Science and Technology, Universiti Kebangsaan Malaysia, Bangi, Selangor, Malaysia \\ 4 Institute of Systems Biology (INBIOSIS), Universiti Kebangsaan Malaysia, Bangi, Selangor, Malaysia \\ 5 Department of Bioprocess Engineering, Faculty of Chemical Engineering, Universiti Teknologi Malaysia, Skudai, Johor, Malaysia \\ 6 Malaysia Genome Institute, Kajang, Selangor, Malaysia \\ 7 Department 4 (Materials \& Environment), Federal Institute of Materials Research and Testing, Berlin, Germany
}

Corresponding Author: Farah Diba Abu Bakar

Email address: fabyff@ukm.edu.my

Background. Aspergillus niger along with many other lignocellulolytic fungi, has been widely used as a commercial workhorse for cellulase production. A fungal cellulase system generally includes three major classes of enzymes i.e. $\beta$-glucosidases, endoglucanases and cellobiohydrolases. Cellobiohydrolases (CBH) are vital to the degradation of crystalline cellulose present in lignocellulosic biomass. However, $A$. niger naturally secretes low levels of $\mathrm{CBH}$. Hence, recombinant production of $A$. niger $\mathrm{CBH}$ is desirable to increase $\mathrm{CBH}$ production yield and also to allow biochemical characterisation of the recombinant $\mathrm{CBH}$ from A. niger.

Methods. In this study, the gene encoding a cellobiohydrolase B (cbhB) from A. niger ATCC 10574 was cloned and expressed in the methylotrophic yeast Pichia pastoris X-33. The recombinant CBHB was purified and characterised to study its biochemical and kinetic characteristics. To evaluate the potential of $\mathrm{CBHB}$ in assisting biomass conversion, $\mathrm{CBHB}$ was supplemented into a commercial cellulase preparation (Cellic ${ }^{\circledR}$ CTec2) and was used to hydrolyse oil palm empty fruit bunch (OPEFB), one of the most abundant lignocellulosic waste from the palm oil industry. To attain maximum saccharification, enzyme loadings were optimised by response surface methodology and the optimum point was validated experimentally. Hydrolysed OPEFB samples were analysed using attenuated total reflectance FTIR spectroscopy (ATR-FTIR) to screen for any compositional changes upon enzymatic treatment.

Results. Recombinant CBHB was over-expressed as a hyperglycosylated protein attached to $\mathrm{N}$-glycans. CBHB was enzymatically active towards soluble substrates such as 4-methylumbelliferyl- $\beta$-D-cellobioside (MUC), $p$-nitrophenyl-cellobioside ( $p N P C$ ) and $p$-nitrophenyl-cellobiotrioside ( $p N P G 3$ ) but was not active towards crystalline substrates like Avicel ${ }^{\circledR}$ and Sigmacell cellulose. Characterisation of purified CBHB using MUC as the model substrate revealed that optimum catalysis occurred at $50{ }^{\circ} \mathrm{C}$ and $\mathrm{pH} 4$ but the enzyme was stable between $\mathrm{pH} 3$ to 10 and 30 to $80^{\circ} \mathrm{C}$. Although $\mathrm{CBHB}$ on its own was unable to digest crystalline substrates, supplementation of CBHB $(0.37 \%)$ with Cellic ${ }^{\circledR}$ CTec2 (30\%) increased saccharification of OPEFB by $27 \%$. Compositional analyses of the treated OPEFB samples revealed that CBHB supplementation reduced peak intensities of both crystalline cellulose $\alpha$ and I $\beta$ in the treated OPEFB samples. 
Discussion. Since CBHB alone was inactive against crystalline cellulose, these data suggested that it might work synergistically with other components of Cellic ${ }^{\circledR} \mathrm{CTec} 2$. CBHB supplements were desirable as they further increased hydrolysis of OPEFB when the performance of Cellic ${ }^{\circledR} \mathrm{CTec} 2$ was theoretically capped at an enzyme loading of $34 \%$ in this study. Hence, $A$. niger CBHB was identified as a potential supplementary enzyme for the enzymatic hydrolysis of OPEFB. 
1 Cellobiohydrolase B of Aspergillus niger Over-expressed in Pichia pastoris Stimulates

2 Hydrolysis of Oil Palm Empty Fruit Bunches

3

4 James Sy-Keen Woon (james.woon@newcastle.edu.my) ${ }^{1,2}$, Mukram Mohamed Mackeen

5 (mukram.mackeen@ukm.edu.my) ${ }^{3,4}$, Rosli Md Illias 5 (r-rosli@utm.my), Nor Muhammad

6 Mahadi (nor.mahadi@gmail.com) ${ }^{4,6}$,William J. Broughton

7 (williamebroughton@gmail.com)7, Abdul Munir Abdul Murad (munir@ukm.edu.my)1, Farah

8 Diba Abu Bakar ${ }^{*}$

9

${ }^{1}$ School of Biosciences and Biotechnology, Faculty of Science and Technology, Universiti

Kebangsaan Malaysia, 43600 UKM Bangi, Selangor, Malaysia.

${ }^{2}$ Present address: Newcastle University Medicine Malaysia, Kota Ilmu, EduCity@Iskandar, 79200 Iskandar Puteri, Johor, Malaysia.

${ }^{3}$ School of Chemical Sciences and Food Technology, Faculty of Science and Technology, Universiti Kebangsaan Malaysia, 43600 UKM Bangi, Selangor, Malaysia.

${ }^{4}$ Institute of Systems Biology (INBIOSIS), Universiti Kebangsaan Malaysia, 43600 UKM Bangi, Selangor, Malaysia.

${ }^{5}$ Department of Bioprocess Engineering, Faculty of Chemical Engineering, Universiti Teknologi Malaysia, 81310 Skudai, Johor, Malaysia.

${ }^{6}$ Malaysia Genome Institute, Jalan Bangi Lama, 43000 Kajang, Selangor Malaysia.

${ }^{7}$ Department 4 (Materials \& Environment), Federal Institute of Materials Research and Testing, Unter den Eichen 87, Berlin, 12205, Germany.

* Corresponding author: Email: fabyff@ukm.edu.my 


\section{Manuscript to be reviewed}

\section{ABSTRACT}

Background. Aspergillus niger along with many other lignocellulolytic fungi, has been widely used as a commercial workhorse for cellulase production. A fungal cellulase system generally includes three major classes of enzymes i.e. $\beta$-glucosidases, endoglucanases and cellobiohydrolases. Cellobiohydrolases $(\mathrm{CBH})$ are vital to the degradation of crystalline cellulose present in lignocellulosic biomass. However, $A$. niger naturally secretes low levels of $\mathrm{CBH}$. Hence, recombinant production of $A$. niger $\mathrm{CBH}$ is desirable to increase $\mathrm{CBH}$ production yield and also to allow biochemical characterisation of the recombinant $\mathrm{CBH}$ from A. niger.

Methods. In this study, the gene encoding a cellobiohydrolase B ( $c b h \mathrm{~B})$ from $A$. niger ATCC 10574 was cloned and expressed in the methylotrophic yeast Pichia pastoris X-33. The recombinant $\mathrm{CBHB}$ was purified and characterised to study its biochemical and kinetic characteristics. To evaluate the potential of $\mathrm{CBHB}$ in assisting biomass conversion, $\mathrm{CBHB}$ was supplemented into a commercial cellulase preparation $\left(\mathrm{Cellic}{ }^{\circledR} \mathrm{CTec} 2\right)$ and was used to hydrolyse oil palm empty fruit bunch (OPEFB), one of the most abundant lignocellulosic waste from the palm oil industry. To attain maximum saccharification, enzyme loadings were optimised by response surface methodology and the optimum point was validated experimentally. Hydrolysed OPEFB samples were analysed using attenuated total reflectance FTIR spectroscopy (ATR-FTIR) to screen for any compositional changes upon enzymatic treatment.

Results. Recombinant CBHB was over-expressed as a hyperglycosylated protein attached to $N$-glycans. CBHB was enzymatically active towards soluble substrates such as 4methylumbelliferyl- $\beta$-D-cellobioside (MUC), $p$-nitrophenyl-cellobioside ( $p$ NPC) and $p$ nitrophenyl-cellobiotrioside ( $p$ NPG3) but was not active towards crystalline substrates like Avicel $^{\circledR}$ and Sigmacell cellulose. Characterisation of purified CBHB using MUC as the model 


\section{Manuscript to be reviewed}

51 substrate revealed that optimum catalysis occurred at $50{ }^{\circ} \mathrm{C}$ and $\mathrm{pH} 4$ but the enzyme was

stable between pH 3 to 10 and 30 to $80{ }^{\circ} \mathrm{C}$. Although $\mathrm{CBHB}$ on its own was unable to digest crystalline substrates, supplementation of $\mathrm{CBHB}(0.37 \%)$ with $\mathrm{Cellic}^{\circledR} \mathrm{CTec} 2(30 \%)$ increased saccharification of OPEFB by $27 \%$. Compositional analyses of the treated OPEFB samples revealed that $\mathrm{CBHB}$ supplementation reduced peak intensities of both crystalline cellulose I $\alpha$ and I $\beta$ in the treated OPEFB samples.

Discussion. Since CBHB alone was inactive against crystalline cellulose, these data suggested that it might work synergistically with other components of Cellic ${ }^{\circledR} \mathrm{CTec} 2$. CBHB supplements were desirable as they further increased hydrolysis of OPEFB when the performance of Cellic ${ }^{\circledR}$ CTec2 was theoretically capped at an enzyme loading of $34 \%$ in this study. Hence, $A$. niger CBHB was identified as a potential supplementary enzyme for the enzymatic hydrolysis of OPEFB.

Abbreviations: ATR-FTIR, attenuated total reflectance Fourier transform infrared spectroscopy; $\mathrm{CBH}$, cellobiohydrolase; $\mathrm{CBM}$, cellulose binding module; CCRD, central composite rotational design; HPLC, high performance liquid chromatography; IMAC, immobilised metal affinity chromatography; MUC, 4-methylumbelliferyl- $\beta$-D-cellobioside; OPEFB, oil palm empty fruit bunch; $p$ NPC, $p$-nitrophenol- $\beta$-D-cellobioside; $p$ NPG3, $p$ nitrophenol- $\beta$-D-cellotrioside; $p$ NPL, $p$-nitrophenol- $\beta$-D-lactoside; RSM, response surface methodology.

\section{INTRODUCTION}

Oil palm empty fruit bunches (OPEFB) are among the most abundant lignocellulosic biomass wastes of the palm oil industry. Research towards the utilisation of oil palm biomass into value-added products is desirable to better manage wastes and reduce carbon footprint as a 


\section{Manuscript to be reviewed}

76 result of OPEFB incineration. In addition, their renewability and low cost make OPEFB an

ideal sugar-rich feed-stock for biofuel production (Ibrahim et al., 2015). Enzymatic hydrolysis of lignocellulosic biomass remains a bottleneck in biofuel production however due to the high cost and relative inefficiencies of lignocellulose degrading enzymes against recalcitrant biomass feed-stocks (Brijwani, Oberoi \& Vadlani, 2010; Fang et al., 2009; KleinMarcuschamer et al., 2012). Aspergillus niger is a filamentous fungus well-known for its ability to produce copious amount of lignocellulose degrading enzymes (Saliu \& Sani, 2012). For this reason, numerous commercial enzyme preparations have been derived from A. niger cultures including Novozymes 188 (Novozymes Inc., 2880 Bagsvard, Denmark), BiocellulaseA (Quest Intl., Irvine, CA 92618, USA) and Cellulase AP 30 K (Amano Enzyme Inc., Nagoya, Aichi 460-8630, Japan) (Verardi et al., 2012). By nature, A. niger secretes large quantities of $\beta$-glucosidases but only limited amounts of cellobiohydrolases $(\mathrm{CBH})$. Hence, characterisation of native A. niger CBHs has been underreported (Dashtban, Schraft \& Qin, 2009; Fang \& Xia, 2015). A related fungus, Trichoderma reesei, secretes large amounts of $\mathrm{CBH}$ but has very low extracellular $\beta$-glucosidase (BGL) activities because most of the activity is bound to the cell wall (Bischof, Ramoni \& Seiboth, 2016). Therefore, enzyme supplements are often required for synergistic reasons to enhance the hydrolytic efficiencies of enzyme cocktails used on lignocellulosic feedstocks. Supplementation is also used because different types of biomass have different properties, therefore they require a set of enzymes that has to be tailor-made (Stockton et al., 1991; Rosgaard et al., 2006). Cellobiohydrolases are essential components of the fungal cellulase system that include three major classes of enzymes i.e. $\beta$-glucosidases, endoglucanases and CBHs (Garvey et al., 2013; Woon et al., 2016a). CBHs are particularly important in biomass degradation due to their hydrolytic activities toward crystalline cellulose that is abundant in lignocellulose (Abdeljabbar, Song \& Link, 2012). CBHs hydrolyse from the termini of 


\section{Manuscript to be reviewed}

101 cellulose chains in a processive manner, releasing cellobiose as the major hydrolysis product

102 (Teeri, 1997). According to the glycoside hydrolase classification system, fungi generally

103

104

105

106

107

108

109

110

111

112

113

114

115 produce two classes of CBHs (Henrissat \& Bairoch, 1996). CBHs that belong to glycoside hydrolase (GH) family 6 (EC 3.2.1.176) are inverting enzymes that cleave from the reducing ends of cellulose chains whilst CBHs of GH family 7 (EC 3.2.1.91) are retaining enzymes that cleave from the non-reducing termini of cellulose chains (Teeri, 1997). Although heterologous expression of CBHs has been widely reported in yeasts (Den Haan et al., 2013) and fungi (Zoglowek et al., 2015), the use of recombinant cellobiohydrolases in the biomass conversion industry has been limited by their expression levels and unpredictable activity profiles caused by non-native glycosylation patterns of the expression hosts (Gao et al., 2012; Jeoh et al., 2008). Apart from glycosylation, CBH activity also depends on other posttranslational modifications such as $\mathrm{N}$-terminal pyroglutamate formation that is commonly observed in crystal structures of Cel7A enzymes. This posttranslational modification however, is lacking in yeast expression systems (Dana et al., 2014). Low yields coupled with low enzymatic activities drive up the costs of enzymatic biomass conversion (KleinMarcuschamer et al., 2012).

The methylotrophic yeast Pichia pastoris grows on simple media and to high densities in flasks and fermenters. It was chosen as the expression host since it also possesses many of the advantages of eukaryotic expression systems including protein processing, protein folding and posttranslational modifications (Cregg, Vedvick \& Raschke 1993). Accordingly, cellobiohydrolase B (CBHB) from $A$. niger ATCC 10574 was cloned and expressed in $P$. pastoris X-33. The enzymatic properties of purified CBHB were characterised and the recombinant $\mathrm{CBHB}$ was added to the commercial enzyme preparation (Cellic $\left.{ }^{\circledR} \mathrm{CTec} 2\right)$ to investigate its synergistic effect on enzymatic hydrolysis of oil palm empty fruit bunches (OPEFB). 


\section{Manuscript to be reviewed}

MATERIALS AND METHODS

128

\section{Microbial strains and cloning vectors}

130

131

132

133

134

135

Escherichia coli strain DH5 $\alpha$ (Promega, Madison, WI) was used for plasmid manipulation and propagation throughout as described by Sambrook \& Russell (2001). The previously isolated cDNA of $c b h \mathrm{~B}$ (GenBank accession number: KR052992.1) was cloned into the pGEM-T Easy cloning vector (Promega) (Woon, Abdul Murad \& Abu Bakar, 2015). P. pastoris strain X-33 (Invitrogen/Life Technologies, Grand Island, NY) was used for the expression of $A$. niger $c b h \mathrm{~B}$. Preparation of media and culturing of yeast transformant were carried out following Invitrogen/Life Technologies Pichia expression system protocols.

\section{Construction of the expression cassette}

The cloning vector harbouring the cDNA of $c b h \mathrm{~B}$ was extracted from E. coli DH5 $\alpha$ cultured in $10 \mathrm{~mL}$ Luria-Bertani medium using the Wizard $^{\circledR}$ Plus SV Minipreps DNA Purification System (Promega). To construct an expression cassette of the target gene, the plasmid from $E$. coli was digested with ClaI and KpnI (New England Biolabs, Beverly, MA) to release the insert, followed by gel purification of the target gene using the MEGAquick-spin ${ }^{\mathrm{TM}}$ Total DNA Fragment Purification kit (INTRON Biotechnology, Gyeonggi-do, South Korea) before it was inserted into the expression vector pPICzaC (Invitrogen/Life Technologies). Manipulation of DNA was carried out using standard procedures (Sambrook \& Russell, 2001).

\section{Transformation of $\boldsymbol{P}$. pastoris and screening of transformants}




\section{Manuscript to be reviewed}

150 Transformation of $P$. pastoris X-33 was performed according to the Invitrogen/Life

151 Technologies Pichia expression system protocol. Transformants containing multiple

152 insertions were selected on yeast extract peptone dextrose plates containing sorbitol (YPDS)

153 and amended with various concentrations of $\operatorname{Zeocin}^{\mathrm{TM}}\left(500,1,000\right.$, and 2,000 $\left.\mu \mathrm{g} \mathrm{mL}^{-1}\right)$.

154 Positive transformants were confirmed by PCR (Lõoke, Kristjuhan \& Kristjuhan, 2011) using

155 the specific primers $\left(5^{\prime}-c b h \mathrm{~B}\right.$ forward:

156 ATCGATGCATCATCATCATCATCATCAGCAGGTT and 3'- $c b h$ B reverse:

157 CCGGTACCTCACAAACACTGCGAGTA) to detect the target gene within the P. pastoris 158 genome.

\section{Production and purification of CBHB}

161

162

163

164

165

166

167

168

Transformants carrying the expression construct $c b h \mathrm{~B} \_\mathrm{pPICZ} \alpha \mathrm{C}$ were inoculated into 100 $\mathrm{mL}$ of buffered glycerol complex medium and cultured to an $\mathrm{OD}_{600}$ of 2 to 3 at $30{ }^{\circ} \mathrm{C}$ with shaking at $240 \mathrm{rpm}$. Then the cells were harvested via centrifugation $(1,500 \mathrm{x} \mathrm{g}, 5 \mathrm{~min})$ and re-suspended in $50 \mathrm{~mL}$ of buffered methanol complex medium. Methanol was added every 24 $\mathrm{h}$ to a final concentration of $1.0 \%(\mathrm{v} / \mathrm{v})$ during the $72 \mathrm{~h}$ incubation (at $30{ }^{\circ} \mathrm{C}$ with shaking at $240 \mathrm{rpm})$. Culture supernatants were clarified by centrifugation $(3,000 \mathrm{x} \mathrm{g}, 5 \mathrm{~min})$ and stored at $-20^{\circ} \mathrm{C}$. CBHB production was verified by SDS-PAGE (12\% polyacrylamide) followed by western-blot analyses using mouse anti His-tag monoclonal antibodies (Cat\#70796, Novagen, Madison, USA) and HRP-conjugated anti-mouse antibodies (Promega) for chemi-luminescent detection on X-ray films. Protein concentrations were determined using the Bradford method (Bradford, 1976).

Culture supernatants containing His $_{6}$-tagged $\mathrm{CBHB}$ recombinant enzymes were purified by immobilised metal-ion affinity chromatography (AKTA prime system from GE Healthcare Bio-Sciences Corp., New Jersey, USA) using a $1 \mathrm{~mL}$ HiTrap chelating column 


\section{Manuscript to be reviewed}

175 charged with $\mathrm{Ni}^{2+}$ ions. The column was equilibrated with $10 \mathrm{~mL}$ binding buffer [50 mM

$176 \mathrm{NaH}_{2} \mathrm{PO}_{4}(\mathrm{pH} 8.0), 0.5 \mathrm{M} \mathrm{NaCl}, 20 \mathrm{mM}$ imidazole]. Crude protein $(1 \mathrm{~mL})$ was loaded onto

177 the column and the resin washed with $10 \mathrm{~mL}$ binding buffer. Bound protein was eluted by a

178 linear gradient of elution buffer $\left[50 \mathrm{mM} \mathrm{NaH}_{2} \mathrm{PO}_{4}(\mathrm{pH} 8.0), 0.5 \mathrm{mM} \mathrm{NaCl}, 50\right.$ to $400 \mathrm{mM}$

179 imidazole]. Eluted fractions that contained high concentrations of proteins were pooled and

180 concentrated using Vivaspin ${ }^{\mathrm{TM}}$ centrifugal concentrators (cut-off of $10 \mathrm{kDa}$ - GE Healthcare

181 Bio-Sciences Corp.).

182

183

184

185

186

187

188

189

190

191

192

193

194

195

196

197

198

199

To assess the extent of $N$-glycosylation of CBHB, $20 \mu \mathrm{g}$ of purified CBHB was deglycosylated using PNGaseF (New England Biolabs, Beverly, MA, USA) according to the manufacturer's instructions. Deglycosylated CBHB was analysed by SDS-PAGE to compare the molecular weight of the enzyme before and after deglycosylation.

\section{Enzyme assays}

The catalytic activity (initial rates) of CBHB was measured using 4-methylumbelliferyl- $\beta$-Dcellobioside (MUC) (Sigma-Aldrich Corp., St. Louis, MO) in a $400 \mu \mathrm{L}$ reaction mixture containing $30 \mathrm{mM}$ citrate buffer ( $\mathrm{pH} 4.0), 0.4 \mathrm{mM}$ MUC and $3 \mu \mathrm{g}$ of purified CBHB. After 15 min incubation at $50{ }^{\circ} \mathrm{C}$, reactions were terminated by adding $100 \mu \mathrm{L}$ of $1.0 \mathrm{M} \mathrm{Na}_{2} \mathrm{CO}_{3}$. Fluorescence of the 4-methylumbelliferyl group released from MUC was determined at excitation and emission wavelengths of 365 and $460 \mathrm{~nm}$, respectively. One unit of enzyme activity was defined as the amount of the enzyme that produced the equivalent of $1 \mu \mathrm{mol}$ product (4-methylumbelliferrone) under optimal conditions in $1 \mathrm{~min}$. Enzyme assays were also performed using $p$-nitrophenyl- $\beta$-D-cellobioside ( $p$ NPC), $p$-nitrophenyl- $\beta$-Dcellobiotrioside ( $p$ NPG3) and $p$-nitrophenyl- $\beta$-D-lactoside ( $p$ NPL) as substrates under similar assay conditions. Optical densities were read at $405 \mathrm{~nm}$ to detect the hydrolysis product ( $p$ nitrophenol). To investigate $\mathrm{CBHB}$ activity towards crystalline substrates, assays were 


\section{Manuscript to be reviewed}

200 performed in $400 \mu \mathrm{L}$ of $30 \mathrm{mM}$ citrate buffer $(\mathrm{pH} 4.0)$ using 1\% (w/v) microcrystalline

201 cellulose Avicel ${ }^{\circledR}$ PH-101 (Sigma-Aldrich) or 1\% (w/v) Sigmacell Cellulose Type 20

202 (Sigma-Aldrich) and $3 \mu \mathrm{g}$ of purified CBHB. Assay mixtures were incubated at $50^{\circ} \mathrm{C}$ for 30

$203 \mathrm{~min}$; reactions were then terminated by boiling for $10 \mathrm{~min}$. The amount of reducing sugar

204 produced was estimated using the dinitrosalicylic (DNS) reagent method (Miller, 1959).

205

206

207

208

209

210

211

212

213

214

215

216

217

218

219

\section{Thermal and pH profiles of CBHB}

Purified CBHB $(3 \mu \mathrm{g})$ was incubated at various temperatures $(30,40,45,50,55,60,70$ and $80^{\circ} \mathrm{C}$ ) in $250 \mu \mathrm{L}$ citrate buffer ( $\mathrm{pH} 4.0,30 \mathrm{mM}$ ) for $30 \mathrm{~min}$. Upon cooling down on ice for 1 min, MUC (at $0.4 \mathrm{mM}$ final concentration) and deionized distilled water were added to top up the reaction mixtures to a final volume of $400 \mu \mathrm{L}$. Residual activities of the treated protein was assayed using the standard protocol described above and MUC as the substrate.

Purified CBHB $(3 \mu \mathrm{g})$ was also incubated at various $\mathrm{pH}$ buffers $(\mathrm{pH} 3-10)$ for $30 \mathrm{~min}$. Subsequently, MUC (at $0.4 \mathrm{mM}$ final concentration) and deionised distilled water were added to top up the reaction mixtures to a final volume of $400 \mu \mathrm{L}$. Residual activities of the treated protein was assayed using the standard protocol described above and MUC as the substrate.

\section{Enzyme kinetics analysis}

Michaelis-Menten kinetics of purified CBHB were determined under optimal catalytic conditions for purified CBHB $\left(3 \mu \mathrm{g}\right.$ or $\left.7.5 \mu \mathrm{g} \cdot \mathrm{mL}^{-1}\right)$ i.e. $50{ }^{\circ} \mathrm{C}$ and $\mathrm{pH} 4.0$ in a $30 \mathrm{mM}$ citrate buffer. Multiple concentrations of MUC ranging from 0.5 to $2.0 \mathrm{mM}$ were used to gather data on enzyme kinetics. A Lineweaver-Burk plot (Lineweaver \& Burk, 1934) was used to calculate the values of $K_{\mathrm{m}}$ and $V_{\max }$ of CBHB.

\section{Effect of metal-ions and reagents on enzyme activity}




\section{Manuscript to be reviewed}

225 Reaction mixtures consisted of $3 \mu \mathrm{g}$ enzyme, $250 \mu \mathrm{L}$ citrate buffer $(\mathrm{pH} 4.0$, final

concentration - $30 \mathrm{mM}$ ), $100 \mu \mathrm{L}$ MUC (final concentration - $0.4 \mathrm{mM}$ ) and $50 \mu \mathrm{L}$ solutions containing different metal ions $\left(\mathrm{Ba}^{2+}, \mathrm{Ca}^{2+}, \mathrm{Co}^{2+}, \mathrm{Cu}^{2+}, \mathrm{Fe}^{2+}, \mathrm{K}^{+}, \mathrm{Mg}^{2+}, \mathrm{Mn}^{2+}, \mathrm{Na}^{+}\right.$and $\left.\mathrm{Zn}^{2+}\right)$ at final concentrations of 1 and $10 \mathrm{mM}$, respectively. The effects of EDTA (1 and $10 \mathrm{mM})$ and urea $(0.1$ and $1.0 \mathrm{M})$ on enzyme activity under standard conditions were also tested.

\section{Enzymatic hydrolysis of OPEFB using Cellic ${ }^{\circledR}$ CTec2 supplemented with CBHB}

Sime Darby Limited (Pulau Carey, Selangor, Malaysia) kindly provided and pre-treated the OPEFB samples as follows: OPEFB samples were dried at $60{ }^{\circ} \mathrm{C}$ to constant mass and ground to pass a $0.25 \mathrm{~mm}$ sieve. To remove surface lignin, $1 \mathrm{~g}$ ground OPEFB was treated with $8 \mathrm{~mL}$ of calcium hydroxide $\left(1 \mathrm{~g} \mathrm{~L}^{-1}\right)$ for $90 \mathrm{~min}$ at $50{ }^{\circ} \mathrm{C}$. Samples were then washed three times with deionised distilled water and recovered by filtration. Then, $20 \%(\mathrm{v} / \mathrm{v})$ of peracetic acid was added at a v/w ratio of $1: 1$ ratio and incubated for $2 \mathrm{~h}$ at $75^{\circ} \mathrm{C}$. Peracetic acid was prepared earlier by mixing $600 \mathrm{~mL}$ of glacial acetic acid with $400 \mathrm{~mL}$ of $30 \%$ hydrogen peroxide at room temperature for $72 \mathrm{~h}$. Pre-treated OPEFB samples were then washed with deionised distilled water until neutral $\mathrm{pH}$, then dried to constant mass at $60{ }^{\circ} \mathrm{C}$.

To investigate the synergistic effect of $\mathrm{CBHB}$ on hydrolysis of OPEFB, purified CBHB (10-50 $\mu \mathrm{g})$ was supplemented to the commercial enzyme cocktail Cellic ${ }^{\circledR}$ CTec2. Saccharification of OPEFB was performed in $1 \mathrm{~mL}$ reaction mixtures containing $25 \mathrm{mM}$ pH 5 sodium acetate buffer and $1 \%(\mathrm{w} / \mathrm{v})$ pre-treated OPEFB at $50{ }^{\circ} \mathrm{C}$ with shaking at $1,000 \mathrm{rpm}$ for 5 h (Thermomixer Comfort, Eppendorf AG, Hamburg, Germany). Production of reducing sugars were measured using the DNS reagent (Miller, 1959) and total reducing sugars (TRS) calculated using the following equation (Farias Silva et al., 2015): 


\section{Manuscript to be reviewed}

250

251

252

253

254

255

256

257

258

259

260

261

262

263

264

265

266

267

268

269

270

271

(1)

Where: $\mathrm{c}\left(\mathrm{mg} \cdot \mathrm{mL}^{-1}\right)=$ concentration of reducing sugars as measured by the DNS assay; $\mathrm{v}(\mathrm{mL})=$ volume of the OPEFB hydrolysis reaction mixture;

$\mathrm{w}(\mathrm{mg})=$ weight of pre-treated OPEFB used in hydrolysis assay.

To achieve maximum saccharification of OPEFB, enzyme loadings were optimised using response surface methods (RSM) and a central composite rotatable design (CCRD) to determine the effects of independent variables on enzymatic hydrolysis. Thirteen experimental runs were formed by Design Expert Version 6.0.10 (Stat Ease Inc., Minneapolis, USA) with five replications at the central points, four replications at the axial points and four replications at the factorial points. The variables were: Cellic ${ }^{\circledR} \mathrm{CTec} 2$ loadings (A) and CBHB loadings (B). Models were deemed suitable when they were significant based on ANOVA (P $<0.05)$ and insignificant based on lack-of-fit tests $(\mathrm{P}>0.05)$ (Whitcomb \& Anderson, 2004). The predicted optimum point was confirmed experimentally in three replications and was validated using Root Mean Squared Deviation (RMSD) as described by Pineiro et al. (2008): 
274 instrument fitted with a universal ATR sampler accessory (ATR-FTIR spectroscopy). The

275 scanning range of the experiment was 650 to $4,000 \mathrm{~cm}^{-1}$.

276

277

278

279

280

281

282

283

\section{RESULTS AND DISCUSSION}

\section{Construction of an expression cassette and transformation of $P$. pastoris}

Transformation of P. pastoris with the expression cassette yielded $>30$ transformants, 16 of which were randomly picked and re-streaked on YPDS plates containing $500 \mu \mathrm{g} \mathrm{mL} \mathrm{m}^{-1}$ Zeocin $^{\mathrm{TM}}$. All grew well but upon transfer to $1,000 \mu \mathrm{g} \mathrm{mL}^{-1} \mathrm{Zeocin}^{\mathrm{TM}}$, the number of survivors declined to 13 while only 8 colonies withstood $2,000 \mu \mathrm{g} \mathrm{mL}{ }^{-1}$ Zeocin $^{\mathrm{TM}}$. These different survival abilities reflected the number of integrations of the expression cassette into the genome of $P$. pastoris. Generally, transformants that are tolerant to higher Zeocin $^{\mathrm{TM}}$ levels are expected to harbour more copies of the gene and hence, higher expression levels of the target gene (Nordén et al., 2011). In this study however, we found that a transformant (K2) tolerant to $1,000 \mu \mathrm{g} \mathrm{mL}{ }^{-1} \mathrm{Zeocin}^{\mathrm{TM}}$ produced the highest amounts of crude proteins $(6.5 \mathrm{mg}$ $\mathrm{mL}^{-1}$ ) amongst all selected transformants with different Zeocin ${ }^{\mathrm{TM}}$ tolerances. Selected transformants were also screened by colony PCR (Lõoke, Kristjuhan \& Kristjuhan, 2011) whereby all positive transformants yielded amplicons of $\sim 1.6 \mathrm{~kb}$ equivalent to the full-length size of $c b h \mathrm{~B}$ (Fig.1).

(Fig.1)

\section{Production and purification of CBHB}

CBHB was over-expressed in the $\mathrm{X}-33$ transformant relative to the host proteins produced by the untransformed X-33 strain (Fig.2). The recombinant CBHB was purified to apparent homogeneity via IMAC purification and its identity confirmed by western blotting (Fig.3). 


\section{Manuscript to be reviewed}

299 Table 1 summarises the purification steps used for CBHB. As much as $0.01 \mathrm{mg} \mathrm{mL}^{-1}(\mathrm{mg}$

300

301

302

303

304

305

306

307

308

309

310

311

312

313

314

315

316

317

318

319

320

321

322

323

enzyme/mL culture) of purified CBHB was recovered following ultracentrifugation and purification by IMAC. Judging from the very low yield of the IMAC-purified sample (9\%)

(Table 1), there was a significant loss of enzymatic activity caused either by protein degradation or protein loss during the purification process.

According to Den Haan et al. (2013), production titres of recombinant CBH in yeasts such as P. pastoris, Saccharomyces cerevisiae and Yarrowia lipolytica varied vastly from $0.0001 \mathrm{mg} \mathrm{mL}^{-1}$ to $\sim 1.7 \mathrm{mg} \mathrm{mL}^{-1}$. In most cases however, expression of $\mathrm{CBH}$ remained very low ranging from 0.0001 to $0.01 \mathrm{mg} \mathrm{mL}^{-1}$. Li et al. (2009) reported the highest level of recombinant $\mathrm{CBH}$ expression in yeast to date. A thermostable $\mathrm{CBH}$ from Chaetomium thermophilum was expressed in P. pastoris at a titre of $\sim 1.7 \mathrm{mg} \mathrm{mL}^{-1}$. Whereas in this study, the $P$. pastoris transformant carrying $c b h \mathrm{~B}$ had an enzymatic activity of $0.02 \mathrm{U} \mathrm{mL}^{-1}$ and the expression level was $0.21 \mathrm{mg} \mathrm{mL}^{-1}$ after $3 \mathrm{~d}$ induction (Table 1).

(Fig.2)(Fig.3)(Table 1)

According to the ProtParam server, the calculated molecular mass of CBHB is $\sim 64$ kDa (http://web.expasy.org/protparam/). However, purified CBHB displayed an apparent molecular weight of $>100 \mathrm{kDa}$ on SDS-PAGE (Fig.4). In silico analyses of CBHB amino acid sequences using the NetNGlyC 1.0 server (http://www.cbs.dtu.dk/services/NetNGlyc/) revealed the presence of two putative $N$-glycosylation sites on CBHB (NGS and NSS, at the $308^{\text {th }}$ and $371^{\text {th }}$ amino acid residues, respectively). De-glycosylation of CBHB using PNGaseF confirmed the presence of the $N$-glycans experimentally. Fig.4 clearly shows that removal of $N$-glycans by PNGaseF reduced the molecular mass of CBHB to a size between 70 and 100 kDa. Besides, CBHB might also be $O$-glycosylated as it contained the Pro/Ser/Thr-rich linker peptide (residues $459-500^{\text {th }}$, GenBank accession number: KR052992.1) that is prone to $O$ glycosylations (Beckham et al., 2012). As such, it is prudent to conclude that CBHB was 
324 produced as a hyper-glycosylated protein in P. pastoris X-33. Glycosylations of CBHs could unpredictably interfere with enzyme activities, stabilities and substrate bindings. The extent and heterogeneity of glycosylations are dependent on many factors such as growth conditions, expression host and the presence of glycan trimming enzymes in the secretome (Beckham et al., 2012). As the effects of glycosylation on CBHs are always case-dependent, a full enzyme characterisation is required to investigate its enzymatic properties and potential usefulness. (Fig.4)

\section{Enzymatic properties of CBHB}

Optimal catalysis of $\mathrm{CBHB}$ with 4-methylumbelliferyl- $\beta$-D-cellobioside (MUC) occurred at $50{ }^{\circ} \mathrm{C}$ and $\mathrm{pH} 4$ (Fig.5A and 5B). The enzyme was stable across a wide range of $\mathrm{pH}$ (pH 3 to 10) and retained more than $80 \%$ of its activity after incubation for 30 min under different $\mathrm{pH}$ conditions (Fig. 5D). As CBHB originated from the mesophilic fungus $A$. niger, it was relatively thermo-tolerant. $\mathrm{CBHB}$ retained more than $80 \%$ of its activity after incubation at 30 to $80{ }^{\circ} \mathrm{C}$ for $30 \mathrm{~min}$ (Fig.5C). To investigate long-term stability at its optimum temperature, CBHB was incubated at $50{ }^{\circ} \mathrm{C}$ for 1 to $5 \mathrm{~h}$ prior to enzyme assays. Under these conditions, CBHB had a half-life of $2 \mathrm{~h}$ and retained $\sim 30 \%$ of its activity after $5 \mathrm{~h}$ of incubation. Stability at $50{ }^{\circ} \mathrm{C}$ is desirable as most commercial cellulase preparations optimally catalyse at the same temperature (Verardi et al., 2012).

(Fig.5)

CBHB was also active towards $p$-nitrophenyl-cellobioside ( $p$ NPC) and $p$-nitrophenylcellobiotrioside ( $p$ NPG3) (Table 2). Both $p$ NPC and $p$ NPG3 are synthetic substrates conjugated at their reducing termini with chromogenic $p$-nitrophenol. In contrast, enzymatic activity was not detected with $p$-nitrophenyl-lactoside ( $p$ NPL) another commonly used substrate for CBH detection (Godbole et al., 1999). As expected CBHB had no effect on 


\section{Manuscript to be reviewed}

349 carboxymethylcellulose (CMC), an amorphous cellulose that is generally used in

350

351

352

353

354

355

356

357

358

359

360

361

362

363

364

365

366

367

368

369

370

371

372

373

endoglucanase assays (Quay et al., 2011). Interestingly however, a recombinant CBH1 from

A. niger expressed in P. pastoris $\mathrm{KM} 71 \mathrm{H}$ was active towards CMC (Li et al., 2012). In this

study, CBHB was unable to hydrolyse the microcrystalline substrates Avicel ${ }^{\circledR}$ and Sigmacell cellulose. Highly crystalline Avice ${ }^{\circledR}$ is commonly used in $\mathrm{CBH}$ assays and it has been so widely used that some CBHs are also known as avicelases (Bronnenmeier, Rücknagel \& Staudenbauer, 1991).

Other reports of CBHs derived from $P$. pastoris mentioned decreased activity towards insoluble crystalline substrates such as Avicel ${ }^{\circledR}$ or bacterial microcrystalline cellulose (BMCC) (Boer, Teeri \& Koivula, 2000; Bronnenmeier, Rücknagel \& Staudenbauer, 1991;

Kanokratana et al., 2008; Woon et al., 2017). Most probably, this decreased activity is linked to the high glycan content (both $N$ - and $O$-linked) of CBHs that potentially perturbs folding of the enzyme, substrate binding and enzyme activity (Gao et al., 2012; Woon et al., 2016b). The $K_{\mathrm{m}}$ and $V_{\max }$ of purified CBHB were calculated to be $0.25 \mathrm{mM}$ and $1.41 \mathrm{U} \mathrm{mg}^{-1}$, respectively using MUC as the substrate (Fig.6). The turnover number $\left(k_{\text {cat }}\right)$ was $2.36 \mathrm{~s}^{-1}$

\section{(Table 2) (Fig.6)}

To test the effect of metal-ions, CBHB was incubated with various salts and assayed for cellobiohydrolase activity against MUC. None of the ions activated the enzyme but at 10 $\mathrm{mM}, \mathrm{Fe}^{3+}$ ions inhibited activity by $\sim 90 \%$ (Fig. 7). Inhibition of cellulase activity by $\mathrm{Fe}^{3+}$ ions was also reported by Wang et al. (2012) who suggested that $\mathrm{Fe}^{3+}$ ions lowered the digestibility of cellulose substrates via oxidation of reducing termini. Inhibition by metal-ions can also be reduced by supplementing reaction mixtures with chelating agents such as ethylenediaminetetraacetic acid (EDTA) (Tejirian \& Xu, 2010). Addition of other metal-ions and reagents $\left(\mathrm{Ca}^{2+}, \mathrm{K}^{+}, \mathrm{Na}^{+}, \mathrm{Zn}^{2+}, \mathrm{Co}^{2+}, \mathrm{Mg}^{2+}, \mathrm{Mn}^{2+} \mathrm{EDTA}^{4-}\right.$ and urea) did not significantly interfere with CBHB activity. At $10 \mathrm{mM}$ however, the presence of $\mathrm{Ba}^{2+}$ and $\mathrm{Cu}^{2+}$ reduced 


\section{Manuscript to be reviewed}

374 catalytic activity by $20-25 \%$. Insensitivity of CBHB towards metal ions and denaturing

375 reagents is a desirable trait in harsh industrial applications.

$376 \quad$ (Fig.7).

377

Attempts to produce $A$. niger $\mathrm{CBHB}$ in Escherichia coli Origami ${ }^{\mathrm{TM}} \mathrm{DE} 3$ failed

378 because the enzyme was localised in insoluble bodies that pelleted with the bacterial cells

379 (Woon, Abdul Murad \& Abu Bakar, 2015). Gurgu \& Barbu (2013) attempted to express

380 CBHB in S. cerevisiae BY4741 (MATa his3 leu2 met15 ura3) but the enzyme was not active

381 against Avicel ${ }^{\circledR}$. Interestingly, expression of CBHB in S. cerevisiae Y294 ( $\alpha$ leu2-3112 ura3-

38252 his3 trp 1-289) attempted by Den Haan et al. (2007) produced a functional enzyme active

383 towards BMCC, albeit at a very low specific activity $\left(0.03 \mathrm{U} \mathrm{mg}^{-1}\right)$. In our work, CBHB of $A$.

384 niger expressed in P. pastoris X-33 produced an enzyme that was active against short-chain

385 glycosides but not against crystalline substrates.

386

387

\section{Enzymatic hydrolysis of OPEFB using Cellic ${ }^{\circledR}$ CTec2 supplemented with CBHB}

388

389

390

391

392

393

394

395

396

397

The enzyme loading was optimised at different concentrations of Cellic ${ }^{\circledR} \mathrm{CTec} 2(1.5$ to $30 \%)$ and CBHB (0.1 to $0.5 \%$ ) (Table 3$)$. The equation that best described enzymatic saccharification of OPEFB was sought by fitting various mathematical models including linear, quadratic and $2 \mathrm{FI}$ to the data. As the $P$ value of ANOVA was lower than $0.05(0.034)$ and the lack of fit test was insignificant $(P$ value $=0.24)($ Table 4$)$, quadratic model best fitted the experimental data. The $R^{2}$ value for this model was 0.93 , showing that only $7 \%$ of the variation in response could not be explained by this model. In terms of decoded values the equation was:

$$
\mathrm{Y}=6.25+0.71 \mathrm{~A}+19.85 \mathrm{~B}-0.0114 \mathrm{~A}^{2}-30.08 \mathrm{~B}^{2}+0.07 \mathrm{AB}
$$


398 where $\mathrm{Y}=$ production of reducing sugar $(\mathrm{mM}) ; \mathrm{A}=$ enzyme loading of Cellic ${ }^{\circledR} \mathrm{CTec} 2(1.5-$

$39930 \%)$; B = enzyme loading of CBHB (0.1-0.5\%).

$400 \quad$ (Table 3)(Table 4)

401

402

403

404

405

406

407

408

409

410

411

412

413

The response-surface diagram indicated that saccharification of OPEFB increased with the concentration of Cellic ${ }^{\circledR}$ CTec2 (Fig.8). At a Cellic ${ }^{\circledR}$ CTec2 concentration of $>25 \%$, production of reducing sugars was less affected by further increases in Cellic ${ }^{\circledR} \mathrm{CTec} 2$ levels. Maximum saccharification of OPEFB was predicted to occur when $30 \%$ Cellic ${ }^{\circledR}$ CTec2 and $0.37 \%$ CBHB were to use in OPEFB hydrolysis.

(Fig.8)

To validate these predicted saccharification optima, an experiment was conducted (in triplicate) using the optimised enzyme loadings. Total reducing sugars (TRS) produced by the optimised mixture amounted to $38.8 \%$ which was in good agreement with the $38.6 \%$ predicted by the RSM model (Table 5, c). Values observed at the optima were subjected to Root Mean Squared Deviation (RMSD) calculations to determine the accuracy of the RSM model. As a rule of thumb, the RSM model is deemed accurate when the value of RMSD is smaller than $10 \%$ of the predicted value (Whitcomb \& Anderson 2004). In our work, the RMSD value at the optima of 1.57 (which is $<10 \%$ of $21.4 \mathrm{mM}$, Table 5, c) indicated that the RSM model accurately predicted optimum enzyme loadings for maximum saccharification. (Table 5)

As mentioned above, saccharification of OPEFB peaked when the concentration of Cellic ${ }^{\circledR}$ CTec2 loaded was more than $25 \%$. To calculate the concentration of Cellic ${ }^{\circledR}$ CTec2 where OPEFB saccharification is maximised, another equation (3) was derived that only considered Cellic ${ }^{\circledR}$ CTec2 (A):

$$
\mathrm{dY} / \mathrm{dA}=0.71-0.0228 \mathrm{~A}
$$




\section{Manuscript to be reviewed}

423 where: $\mathrm{A}=$ enzyme loading of Cellic ${ }^{\circledR}$ CTec2 (1.5 to $\left.30 \%\right)$.

424

425

426

427

428

429

430

431

432

A calculation based on equation (4) indicated that maximum saccharification of

OPEFB occurred when $33.8 \%$ Cellic $^{\circledR}$ CTec2 was added. CBHB supplements were desirable as they further increased hydrolysis of OPEFB when the performance of Cellic ${ }^{\circledR} \mathrm{CTec} 2$ was theoretically capped at an enzyme loading of $33.8 \%$ (producing only $17.2 \mathrm{mM}$ of reducing sugars or $31.1 \%$ TRS).

Using the optimised enzyme loadings containing $29.96 \%$ Cellic ${ }^{\circledR} \mathrm{CTec} 2$ and $0.37 \%$ $\mathrm{CBHB}$, reducing sugar production was increased to $21.5 \mathrm{mM}$ (or $38.8 \% \mathrm{TRS}$ ), equivalent to a $27.2 \%$ enhancement over the un-supplemented samples or a $25 \%$ increase over the theoretical maximum saccharafication using Cellic ${ }^{\circledR}$ CTec2 alone (Table 5).

Use of FTIR has been proven to be one of the most useful methods for the characterisation of natural cellulose fibres. Furthermore, FTIR can provide researchers with further information on the super-molecular structure and the chemical compositions of cellulose fibres with minimal efforts in sample preparation (Fan, Dai \& Biao, 2012). Following addition of CBHB, the ATR-FTIR spectra of OPEFB samples shifted (Fig. 9) implying compositional changes as different functional groups absorb infra-red at other wavelengths (Berthomieu \& Hienerwadel, 2009). Supplementation with CBHB significantly reduced peak intensities at 3,274 and $3,220 \mathrm{~cm}^{-1}$ that are related to the presence of crystalline Cellulose I $\beta\left(3,274 \mathrm{~cm}^{-1}\right)$ and Cellulose I $\alpha\left(3,220 \mathrm{~cm}^{-1}\right)$ (Popescu et al., 2013) (Another peak at $1,038 \mathrm{~cm}^{-1}$ was unassigned however based on information currently available). In other words, supplementing Cellic ${ }^{\circledR}$ CTec2 with CBHB had appreciably reduced crystalline cellulose content in OPEFB.

(Fig.9)

DNS assays showed that removal of crystalline cellulose by CBHB corresponded to an increase in reducing sugar levels as insoluble cellulose was converted into soluble sugars 


\section{Manuscript to be reviewed}

448 (Table 5). Since CBHB alone is inactive against crystalline cellulose, these data suggest that it

449 might work synergistically with other components of Cellic ${ }^{\circledR}$ CTec2. Similar observations had

450 been reported for hydrolysis of OPEFB by Thielavia terrestris CBH7B (Woon et al., 2016b)

451 and degradation of cotton fibres by P. decumbens CBHI (Gao et al., 2012).

452

\section{CONCLUSIONS}

454 Cellobiohydrolase B from A. niger was over-expressed in P. pastoris. The recombinant

455 CBHB functioned optimally at $50^{\circ} \mathrm{C}$ and $\mathrm{pH}$ 4. This enzyme, originated from a known

456 mesophilic fungus, displayed moderate thermal stability as it retained more than $80 \%$ residual

457 activity upon incubation at $80{ }^{\circ} \mathrm{C}$ for $30 \mathrm{~min}$. The kinetic constants $K_{\mathrm{m}}$ and $V_{\max }$ of CBHB

458 towards MUC substrate were $0.25 \mathrm{mM}$ and $1.41 \mathrm{U} \mathrm{mg}^{-1}$, respectively. Supplementation of the

459 commercial cellulase cocktail Cellic ${ }^{\circledR}$ CTec2 with this enzyme boosted saccharification of

460 OPEFB by 27\%. Recombinant CBHB from $A$. niger is thus a useful supplement towards

461 commercial enzyme cocktails such as Cellic ${ }^{\circledR}$ CTec2 in converting OPEFB to simple sugars.

\section{ACKNOWLEDGEMENTS}

The authors acknowledge the Centre for Research and Instrumentation Management (CRIM) at the Universiti Kebangsaan Malaysia for technical support. The MyBrain15 scholarship granted to James Woon Sy-Keen is gratefully acknowledged.

Abdeljabbar DM, Song HJ, Link AJ. 2012. Trichoderma reesei cellobiohydrolase II is associated with the outer membrane when overexpressed in Escherichia coli. Biotechnology Letters 34:91-96.

Beckham GT, Dai Z, Matthews JF, Momany M, Payne CM, Adney WS, Baker SE, Himmel ME. 2012. Harnessing glycosylation to improve cellulase activity. Current Opinion in Biotechnology 23:338-345.

Berthomieu C, Hienerwadel R. 2009. Fourier transform infrared (FTIR) spectroscopy. 


\section{Manuscript to be reviewed}

Photosynthesis Research 101:157-170.

Bischof RH, Ramoni J, Seiboth B. 2016. Cellulases and beyond: the first 70 years of the enzyme producer Trichoderma reesei. Microbial Cell Factories 15:106.

Boer H, Teeri TT, Koivula A. 2000. Characterization of Trichederma reesei cellobiohydrolase Cel7a secreted from Pichia pastoris using two different promoters. Biotechnology Bioengineering 69:486-494.

Bradford M. 1976. Rapid and sensitive method for quantification of microgram quantities of protein utilizing principle of protein-dye-binding. Analytical Biochemistry 72:248-254.

Brijwani K, Oberoi HS, Vadlani PV. 2010. Production of a cellulolytic enzyme system in mixed-culture solid-state fermentation of soybean hulls supplemented with wheat bran. Process Biochemistry 45:120-128.

Bronnenmeier K, Rücknagel KP, Staudenbauer WL. 1991. Purification and properties of a novel type of exo-1,4-beta-glucanase (avicelase II) from the cellulolytic thermophile Clostridium stercorarium. European Journal of Biochemistry 200:379-385.

Cregg JM, Vedvick TS, Raschke. 1993. Recent advances in the expression of foreign genes in Pichia pastoris. Biotechnology 11(8):905-910.

Dana CM, Fagerstrom AD, Roche CM, Kal SM, Chokhawala HA, Blanch HW, Clark DS. 2014. The importance of pyroglutamate in cellulase Cel7A. Biotechnology and Bioengineering 111(4): 842-847.

Dashtban M, Schraft H, Qin W. 2009. Fungal bioconversion of lignocellulosic residues; Opportunities \& perspectives. International Journal of Biological Sciences 5:578-595.

Den Haan R, Kroukamp H, Van Zyl JHD, Van Zyl WH. 2013. Cellobiohydrolase secretion by yeast: Current state and prospects for improvement. Process Biochemistry 48:1-12.

Den Haan R, Mcbride JE, Grange DCL, Lynd LR, Van Zyl WH. 2007. Functional expression of cellobiohydrolases in Saccharomyces cerevisiae towards one-step conversion of cellulose to ethanol. Enzyme and Microbial Technology 40:1291-1299.

Fan M, Dai D, Huang B. 2012. Fourier transform infrared spectroscopy for natural fibres. In: Salih SM, ed. Fourier Transform - Materials Analysis. Rijeka: InTech, 45-68.

Fang H, Xia L. 2015. Heterologous expression and production of Trichoderma reesei cellobiohydrolase II in Pichia pastoris and the application in the enzymatic hydrolysis of corn stover and rice straw. Biomass and Bioenergy 78:99-109.

Fang X, Yano S, Inoue H, Sawayama S. 2009. Strain improvement of Acremonium cellulolyticus for cellulase production by mutation. Journal of Bioscience and Bioengineering 107:256-261.

Farias Silva CE, Belo Gois GNS, Silva LMO, Garcia Almeida RMR, Souza Abud AK. 2015. Citric waste saccharification under different chemical treatments. Acta Scientarium Technology 37:387-395.

Gao L, Gao F, Wang L, Geng C, Chi L, Zhao J, Qu J. 2012. N-glycoform diversity of cellobiohydrolase I from Penicillium decumbens and synergism of nonhydrolytic glycoform in cellulose degradation. Journal of Biological Chemistry 287:1590615915.

Garvey M, Klose H, Fischer R, Lambertz C, Commandeur U. 2013. Cellulases for biomass degradation: Comparing recombinant cellulase expression platforms. Trends in Biotechnology 31:581-593.

Godbole S, Decker SR, Nieves RA, Adney WS, Vinzant TB, Baker JO, Thomas SR, Himmel ME. 1999. Cloning and expression of Trichoderma reesei cellobiohydrolase I in Pichia pastoris. Biotechnological Progress 15:828-833. 
Gurgu L, Barbu V. 2013. Studies about expression of CbhB encoding gene from Aspergillus niger into Saccharomyces cerevisiae. Romanian Biotechnological Letters 18:79757982.

Henrissat B, Bairoch A. 1996. Updating the sequence-based classification of glycosyl hydrolases. Biochemical Journal 316:695-696.

Ibrahim MF, Abd-Aziz S, Ezreeza M, Yusoff M, Phang LY, Hassan MA. 2015. Simultaneous enzymatic saccharification and ABE fermentation using pretreated oil palm empty fruit bunch as substrate to produce butanol and hydrogen as biofuel. Renewable Energy 77: 447-455.

Jeoh T, Michener W, Himmel ME, Decker SR, Adney WS. 2008. Implications of cellobiohydrolase glycosylation for use in biomass conversion. Biotechnology for Biofuels 1:10.

Kanokratana P, Chantasingh D, Champreda V, Tanapongpipat S, Pootanakit K, Eurwilaichitr L. 2008. Identification and expression of cellobiohydrolase (CBHI) gene from an endophytic fungus, Fusicoccum sp. (BCC4124) in Pichia pastoris. Protein Expression and Purification 58:148-153.

Klein-Marcuschamer D, Oleskowicz-Popiel P, Simmons BA., Blanch HW. 2012. The challenge of enzyme cost in the production of lignocellulosic biofuels. Biotechnology and Bioengineering 109:1083-1087.

Li YL, Li H, Li AN, Li DC. 2009. Cloning of a gene encoding thermostable cellobiohydrolase from the thermophilic fungus Chaetomium thermophilum and its expression in Pichia pastoris. Journal of Applied Microbiology 106:1867-1875.

Li G, Chai C, Fan S, Zhao L. 2012. Cloning of a cellobiohydrolase gene (cbh1) from Aspergillus niger and heterogenous expression in Pichia pastoris. Advanced Materials Research 347-353: 2443-2447.

Lineweaver H, Burk D. 1934. The determination of enzyme dissociation constants. Journal of the American Chemical Society 56:658-666.

Lõoke M, Kristjuhan K, Kristjuhan A. 2011. Extraction of genomic DNA from yeast for PCR-based applications. Biotechniques 50:325-328.

Miller GL. 1959. Use of dinitrosalicyclic reagent for determination of reducing sugar. Analytical Chemistry 31:426-428.

Nordén K, Agemark M, Danielson JÅH, Alexandersson E, Kjellbom P, Johanson U. 2011. Increasing gene dosage greatly enhances recombinant expression of aquaporins in Pichia pastoris. BMC Biotechnology 11:47.

Pineiro G, Perelman S, Guerschman JP, Paruelo JM. 2008. How to evaluate models : Observed vs predicted or predicted vs observed? or predicted vs observed ? Ecological Modelling 216:316-322.

Popescu MC, Froidevaux J, Navi P, Popescu CM. 2013. Structural modifications of Tilia cordata wood during heat treatment investigated by FT-IR and 2D IR correlation spectroscopy. Journal of Molecular Structure 1033:176-186.

Quay DHX, Abu Bakar FD, Rabu A, Said M, Illias RM, Mahadi NM, Hassan O, Abdul Murad AM. 2011. Overexpression, purification and characterization of the Aspergillus niger endoglucanase, EglA, in Pichia pastoris. African Journal of Biotechnology 10:2101-2111.

Rosgaard L, Pedersen S, Cherry JR, Harris P, Meyer AS. 2006. Efficiency of new fungal cellulase systems in boosting enzymatic degradation of barley straw lignocellulose. Biotechnological Progress 22:493-498.

Saliu BK, Sani A. 2012. Bioethanol potentials of corn corb hydrolysed using cellulases of Aspergillus niger and Penicillum decumbens. Experimental and Clinical Sciences International Journal 11:468-479. 


\section{Manuscript to be reviewed}

575 Sambrook J, W Russell D. 2001. Molecular Cloning: A Laboratory Manual. New York:

576

577

578

579

580

581

582

583

584

585

586

587

588

589

590

591

592

593

594

595

596

597

598

599

600

601

602

603

604

605

606

607

608

609

610 Cold Spring Harbour Lab Press.

Stockton BC, Mitchell DJ, Grohmann K, Himmel ME. 1991. Optimum $\beta$-D-glucosidase supplementation of cellulase for efficient conversion of cellulose to glucose. Biotechnology Letters 13(1):57-62.

Teeri TT. 1997. Crystalline cellulose degradation: New insight into the function of cellobiohydrolases. Trends in Biotechnology 15:160-167.

Tejirian A, Xu F. 2010. Inhibition of cellulase-catalyzed lignocellulosic hydrolysis by iron and oxidative metal ions and complexes. Applied and Environmental Microbiology 76:7673-7682.

Verardi A, Bari ID, Ricca E, Calabrò V. 2012. Hydrolysis of lignocellulosic biomass : Current status of processes and technologies and future perspectives. In: Lima \& Natalense, ed. Bioethanol. Rijeka: InTech, 95-121.

Wang G, Zhang X, Wang L, Wang K, Peng F, Wang L. 2012. The activity and kinetic properties of cellulases in substrates containing metal ions and acid radicals. Advances in Biological Chemistry 2:390-395.

Whitcomb PJ, Anderson MJ. 2004. RSM Simplified: Optimizing Processes Using Response Surface Methods for Design of Experiments. Florida: CRC Press.

Woon JSK, Abdul Murad AM, Abu Bakar FD. 2015. Isolation, molecular cloning and expression of cellobiohydrolase B (CbhB) from Aspergillus niger in Escherichia coli. AIP Conference Proceedings 1678:5-9.

Woon JSK, Mackeen MM, Sudin AH bin, Mahadi NM, Illias RM, Abdul Murad AM, Abu Bakar FD. 2016a. Production of an oligosaccharide-specific cellobiohydrolase from the thermophilic fungus Thielavia terrestris. Biotechnology Letters 38:825-832.

Woon JSK, Mackeen MM, Mahadi NM, Illias RM, Abdul Murad AM, Abu Bakar FD. 2016b. Expression and characterization of a cellobiohydrolase (CBH7B) from the thermophilic fungus Thielavia terrestris in Pichia pastoris. Biotechnology and Applied Biochemistry 63:690-698.

Woon JSK, King, PJH, Mackeen MM, Mahadi NM, Wan Seman WMK, Broughton WJ, Abdul Murad AM, Abu Bakar FD. 2017. Cloning, production and characterization of a glycoside hydrolase family 7 enzyme from the gut microbiota of the termite Coptotermes curvignathus. Molecular Biotechnology 59: 271-283.

Zoglowek M, Lübeck PS, Ahring BK, Lübeck M. 2015. Heterologous expression of cellobiohydrolases in filamentous fungi - An update on the current challenges, achievements and perspectives. Process Biochemistry 50:211-220. 


\section{Table $\mathbf{1}$ (on next page)}

Purification of $A$. niger CbhB expressed in P. pastoris X-33

$\mathrm{a} U=$ Amount of enzyme required to produce $1 \mu \mathrm{mol}$ of methylumbeliferone per min under specific conditions.

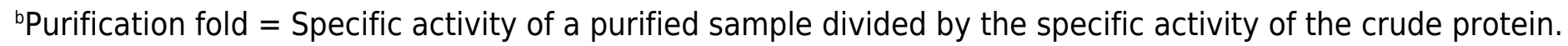
cYield $=$ Total activity a purified sample divided by the total activity of the crude protein. 
1 Table 1 Purification of $A$. niger CBHB expressed in P. pastoris X-33

2

\begin{tabular}{|c|c|c|c|c|c|c|c|}
\hline Purification steps & $\begin{array}{c}\text { Volume } \\
\text { (mL) }\end{array}$ & $\begin{array}{l}\text { Activity } \\
\left.\text { (U.mL }{ }^{-1}\right)\end{array}$ & $\begin{array}{c}\text { Total } \\
\text { activity } \\
(\mathbf{U})^{\mathrm{a}}\end{array}$ & $\begin{array}{c}\text { Total } \\
\text { protein } \\
\text { (mg) }\end{array}$ & $\begin{array}{l}\text { Specific } \\
\text { activity } \\
\left(\mathbf{U}^{-m^{-1}}\right)\end{array}$ & $\begin{array}{l}\text { Purification } \\
\text { fold }^{b}\end{array}$ & $\begin{array}{c}\text { Yield }^{\mathrm{c}} \\
(\%)\end{array}$ \\
\hline Crude protein & 100 & 0.02 & 2.00 & 20.8 & 0.096 & 1 & 100 \\
\hline Ultracentrifugation & 4 & 0.20 & 0.80 & 3.96 & 0.201 & 2.1 & 40 \\
\hline IMAC & 1 & 0.18 & 0.18 & 0.99 & 0.182 & 1.9 & 9 \\
\hline
\end{tabular}

$3 \overline{\mathrm{a}}=$ Amount of enzyme required to produce $1 \mu \mathrm{mol}$ of methylumbeliferone per min under specific 4 conditions.

5 burification fold $=$ Specific activity of a purified sample divided by the specific activity of the crude 6 protein.

$7 \quad{ }^{c}$ Yield = Total activity a purified sample divided by the total activity of the crude protein.

8

9

10

11

12

13

14

15

16

17

18

19

20

21

22

23 


\section{Table 2 (on next page)}

\section{Substrate specificities of purified CbhB}

N.D: not detected within the concentration range of the standard chemical compounds used in the calibration curves.

${ }^{a}$ The range of $p N P$ concentrations used in the calibration curve was $0.03-0.21 \mu \mathrm{mol}$.

${ }^{\mathrm{b}}$ The range of glucose concentrations used in the DNS calibration curve was $0.25-8.0 \mu \mathrm{mol}$. 
1 Table 2 Substrate specificities of purified CBHB assayed at $50^{\circ} \mathrm{C}, \mathrm{pH} 4$.

\begin{tabular}{cccccccc}
\hline Substrate & MUC & $p$ NPC & $p$ NPG3 & $p$ NPL & CMC & Avicel $^{\circledR}$ & $\begin{array}{c}\text { Sigmacell } \\
\text { cellulose }\end{array}$ \\
\hline $\begin{array}{c}\text { Specific } \\
\text { activity } \\
\left({\left.\mathrm{U} . \mathrm{mg}^{-1}\right)}^{-1}\right.\end{array}$ & 0.19 & 0.15 & 0.11 & N.D & N.D & N.D & N.D $^{\mathrm{b}}$ \\
\hline
\end{tabular}

2

3

4

5

6

7

8

9

10

11

12

13

14

15

16

17

18

19

20

21

22

23

24

25

26

27

28

29

30

31

32

33

34

Abbreviations of substrates tested are as follow:

$\mathrm{MUC}=4$-methylumbelliferyl $\beta$-D-cellobioside; $p \mathrm{NPC}=p$-nitrophenol- $\beta$-D-cellobioside; $p \mathrm{NPG} 3$, $p$-nitrophenol- $\beta$-D-cellotrioside; $p \mathrm{NPL}, p$-nitrophenol- $\beta$-D-lactoside; $\mathrm{CMC}=$ carboxymethylcellulose.

N.D: not detected within the concentration range of the standard chemical compounds used in the calibration curves.

${ }^{a}$ The range of $p \mathrm{NP}$ concentrations used in the calibration curve was 0.03-0.21 $\mu \mathrm{mol}$.

${ }^{b}$ The range of glucose concentrations used in the DNS calibration curve was $0.25-8.0$ $\mu \mathrm{mol}$.

3

.

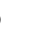

7

8

.

20

.


35

36

37

38

39

40

41

42 


\section{Table 3(on next page)}

Experimental design and results of CCRD for enzymatic hydrolysis of pre-treated oil palm empty fruit bunches (OPEFB).

${ }^{\mathrm{a}}(\% \mathrm{w} / \mathrm{w})=(\mathrm{mg}$ enzyme $/ \mathrm{mg}$ pre-treated OPEFB $) \times 100 \%$ 
1 Table 3 Experimental design and results of CCRD for enzymatic hydrolysis of pre-treated oil palm empty 2 fruit bunches (OPEFB).

3

\begin{tabular}{lllcc}
\hline \multirow{2}{*}{$\begin{array}{l}\text { Run } \\
\text { number }\end{array}$} & $\begin{array}{l}\text { A: Cellic } \\
(\% \mathbf{w} / \mathbf{w})^{\mathbf{a}}\end{array}$ & CTec2 & $\begin{array}{l}\text { B: CBHB } \\
(\mathbf{\%} \text { w/w) }\end{array}$ & \multicolumn{2}{c}{$\begin{array}{c}\text { Reducing sugar } \\
\text { production(mM) }\end{array}$} \\
\hline 11 & 15.3 & 0.3 & 18.8 & 18.0 \\
12 & 15.3 & 0.3 & 18.6 & 18.0 \\
1 & 5.5 & 0.1 & 13.0 & 11.5 \\
6 & 29.0 & 0.3 & 21.3 & 21.1 \\
4 & 25.0 & 0.5 & 19.7 & 20.2 \\
2 & 25.0 & 0.1 & 19.4 & 18.7 \\
5 & 1.5 & 0.3 & 9.5 & 10.5 \\
13 & 15.3 & 0.3 & 18.4 & 18.0 \\
8 & 15.3 & 0.6 & 16.8 & 16.4 \\
9 & 15.3 & 0.3 & 18.0 & 18.0 \\
3 & 5.5 & 0.5 & 12.7 & 12.4 \\
7 & 15.3 & 0.0 & 13.5 & 14.8 \\
10 & 15.3 & 0.3 & 16.4 & 18.0 \\
\hline
\end{tabular}

5

6

7

8

9

10

11

12

13

14

15

16

17

18

19

20

21

22

23

24 


\section{Table 4 (on next page)}

ANOVA for response surface models that describe the enzymatic saccharification of pretreated oil palm empty fruit bunch (OPEFB) 
1 Table 4 ANOVA for response surface models that describe the enzymatic saccharification of pre-treated 2 oil palm empty fruit bunch (OPEFB)

3

\begin{tabular}{lllllll}
\hline Source & $\begin{array}{l}\text { Sum of } \\
\text { Squares }\end{array}$ & $\begin{array}{l}\text { Degree } \\
\text { of } \\
\text { freedom }\end{array}$ & $\begin{array}{l}\text { Mean } \\
\text { Square }\end{array}$ & $\begin{array}{l}\boldsymbol{F} \\
\text { value }\end{array}$ & $\begin{array}{l}\boldsymbol{P} \text { value } \\
\text { Prob }>F\end{array}$ & $\mathbf{R}^{2}$ \\
\hline
\end{tabular}

Sequential Model Sum of Squares

$\begin{array}{lllllll}\text { Linear } & 116 & 2 & 57.8 & 22.1 & 0.0002 & 0.82 \\ \text { 2FI } & 0.08 & 1 & 0.08 & 0.03 & 0.8685 & 0.82 \\ \text { Quadratic } & 16.2 & 2 & 8.08 & 5.69 & 0.0340 & 0.93 \\ \text { Cubic } & & 4.21 & 2 & 2.11 & 1.8400 & 0.96\end{array}$

Lack of Fit tests

\begin{tabular}{lllllll} 
Linear & 22.4 & 6 & 3.73 & 3.92 & 0.1034 & - \\
2FI & 22.3 & 5 & 4.46 & 4.69 & 0.0797 & - \\
Quadratic & 6.1 & 3 & 2.04 & 2.15 & 0.2365 & - \\
Cubic & 1.92 & 1 & 1.92 & 2.02 & 0.2286 & - \\
Pure Error & 3.80 & 4 & 0.95 & & & - \\
\hline
\end{tabular}

4

5 


\section{Table 5 (on next page)}

Enzymatic hydrolysis of oil palm empty fruit bunch (OPEFB) by Cellic ${ }^{\circledR} \mathrm{CTec} 2$ and $\mathrm{CbhB}$

a $0.37 \%$ (mg enzyme/mg OPEFB) of CbhB was added

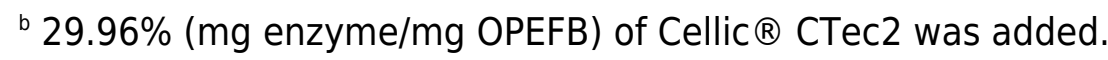

${ }^{c}$ Total reducing sugar (TRS) was calculated based on equation (1).

${ }^{\mathrm{d}}$ Values predicted by RSM model is bracketed.

e $P<0.005$; a significant increase from (b) to (c). 
1 Table 5 Enzymatic hydrolysis of oil palm empty fruit bunch (OPEFB) by Cellic ${ }^{\circledR}$ CTec2 and CBHB

\section{Samples}

\section{Reducing sugar}

$(\mathbf{m M})$

0

$16.9 \pm 0.3$

(b) OPEFB hydrolysed by Cellic ${ }^{\circledR}$

$\mathrm{CTec} 2^{\mathrm{b}}$

(c) OPEFB hydrolysed by Cellic ${ }^{\circledR}$

$\mathrm{CTec} 2^{\mathrm{b}}$ and $\mathrm{CBHB}^{\mathrm{a}}$
$21.5 \pm 1.3$
$38.8 \pm 2.4$

$(21.4)^{\mathrm{d}}$

\section{Total reducing}

sugars $(\%)^{\mathbf{c}}$

Increase in reducing sugar production

$27.2^{\mathrm{e}}$

$(\%)^{\mathrm{c}}$

2

3 a $37 \mu \mathrm{g}$ or $0.0067 \mathrm{U}$ of CBHB was added

4 b $2,996 \mu \mathrm{g}$ or 0.36 FPU of Cellic ${ }^{\circledR}$ CTec2 was added.

$5 \quad c$ Total reducing sugar (TRS) was calculated based on equation (1).

$6{ }^{\mathrm{d}}$ Values predicted by RSM model is bracketed.

$7 \quad$ e $\mathrm{P}<0.005$; a significant increase from (b) to (c).

8 
Figure 1

Agarose gel electrophoresis profiles of DNA extracted from P. pastoris X-33 transformants.

Lane 1: Positive PCR control (expression cassette $c b h B \_p P I C Z \alpha C$ used as DNA template), Lane 2: Negative PCR control (without DNA template), Lane M: molecular weight marker, Lanes 3 to 6: DNA amplified from colonies of $P$. pastoris $\mathrm{X}-33$ transformed with $c b h \mathrm{~B}$ (K1-K4).

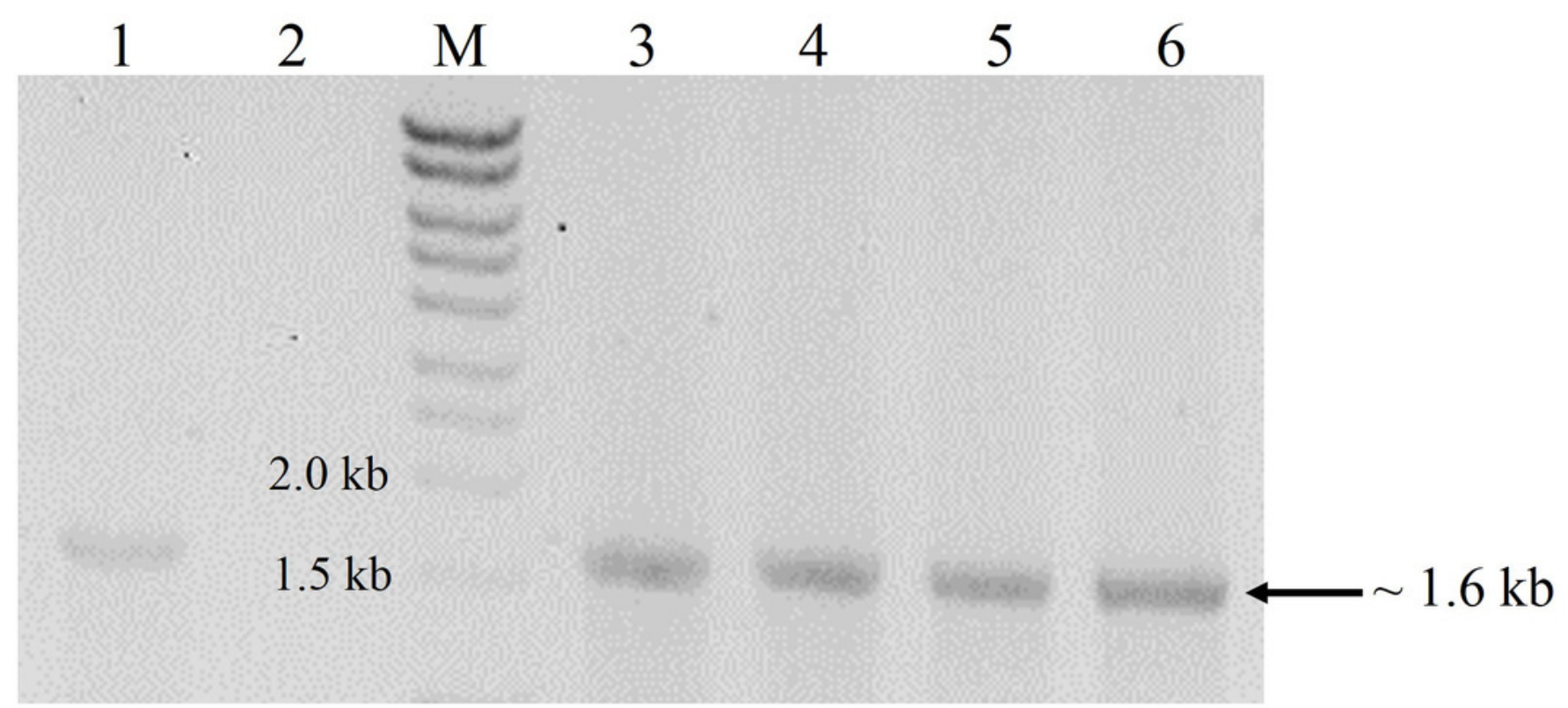


Figure 2

Sodium dodecyl sulfate-polyacrylamide gel electrophoresis (SDS-PAGE) profiles of concentrated crude protein extracts from $P$. pastoris X-33

Lane M: molecular weight marker, Lane 1: concentrated crude proteins from untransformed P. pastoris X-33, Lane 2: concentrated crude proteins from a $P$. pastoris X-33 transformant (K2) harbouring the expression cassette $c b h \mathrm{~B} \_p P I C Z \alpha C$. The black arrow indicates recombinant $\mathrm{CbhB}$. 

$\mathrm{M}$
1
2

$140 \mathrm{kDa}$

$100 \mathrm{kDa}$

$70 \mathrm{kDa}$ 
Figure 3

Western detection of purified CbhB from $P$. pastoris X-33

Lane M: molecular weight marker, Lane 1: Negative control (concentrated crude proteins from untransformed $P$. pastoris X-33), Lane 2: purified CbhB.

$\mathrm{M}$

1

2

$97 \mathrm{kDa}$

$66 \mathrm{kDa}$ 


\section{Figure 4}

Sodium dodecyl sulfate-polyacrylamide gel electrophoresis (SDS-PAGE) profiles of purified CbhB.

Lane M: molecular weight marker, Lane 1: IMAC purified CbhB, Lane 2: IMAC- purified CBHB deglycosylated using PNGaseF.

$\begin{array}{lll}M & 1 & 2\end{array}$

$140 \mathrm{kDa}$

$100 \mathrm{kDa}$

$70 \mathrm{kDa}$

$35 \mathrm{kDa}$

$\longleftarrow$ pNGaseF,

$\sim 36 \mathrm{kDa}$ 
Figure 5

Enzyme activity profiles of CbhB

(A) CbhB activity profile over a range of temperatures displaying the optimum temperature,

(B) $\mathrm{CbhB}$ activity profile over a range of $\mathrm{pH}$ showing the optimum $\mathrm{pH},(\mathrm{C}) \mathrm{CbhB}$ activity profile showing thermostability after exposure to different temperatures $(30,40,45,50,55,60,70$, $80^{\circ} \mathrm{C}$ ) for $30 \mathrm{~min}$ and (D) CbhB activity profile displaying $\mathrm{pH}$ stability after exposure to various $\mathrm{pH}$ ( $\mathrm{pH} 3$ to 10 ) for 30 min. All assays were performed using 4-methylumbelliferyl $\beta$ D-cellobioside (MUC) as the substrate.
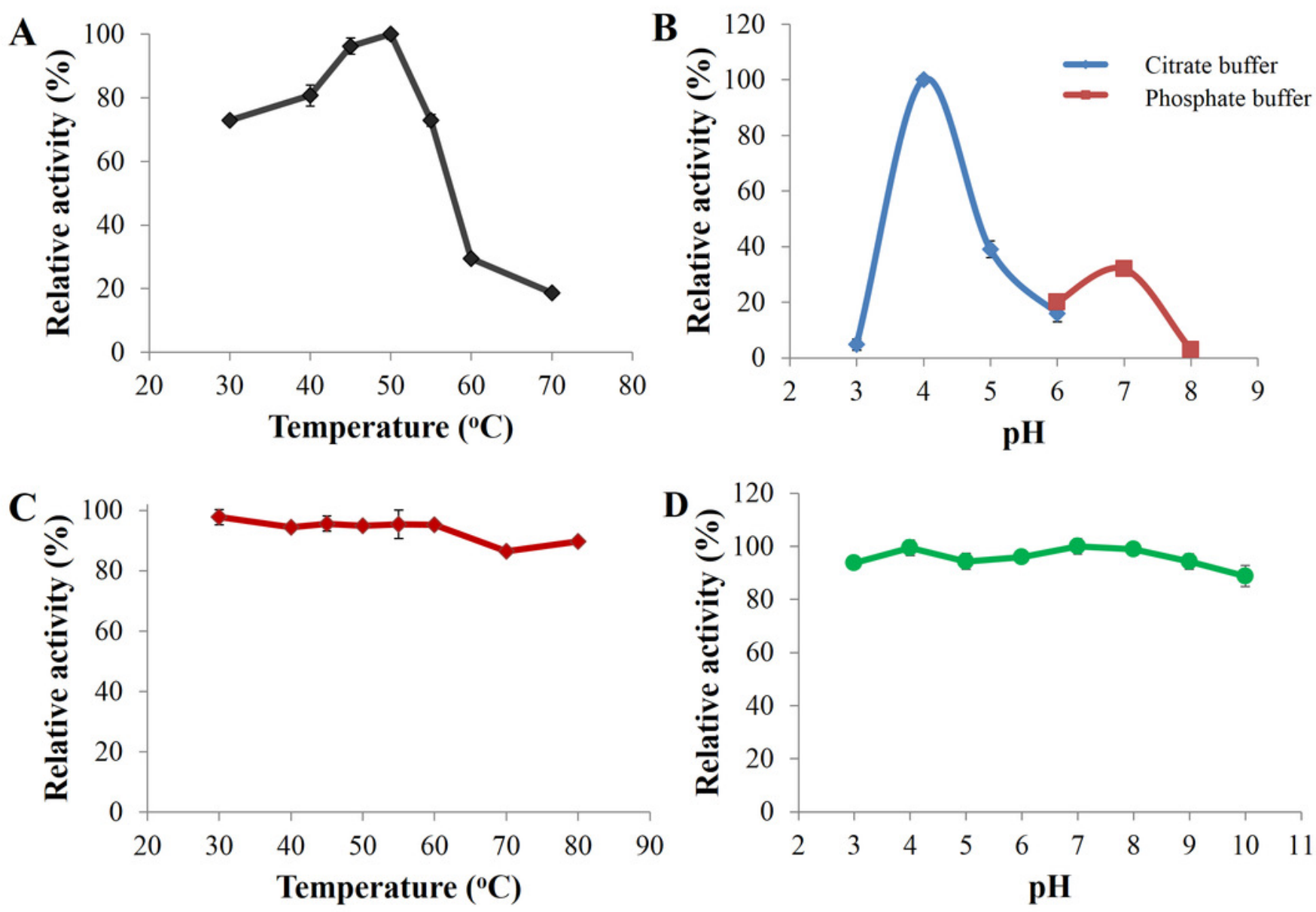
Figure 6

Lineweaver-Burk plot of purified $\mathrm{CbhB}$ assayed at $50^{\circ} \mathrm{C}$ and $\mathrm{pH} 4$ using different 4methylumbelliferyl- $\beta$-D-cellobioside (MUC) substrate concentrations $(0.5 \mathrm{mM}, 1.0 \mathrm{mM}$, $1.5 \mathrm{mM}$ and $2.0 \mathrm{mM}$ ).

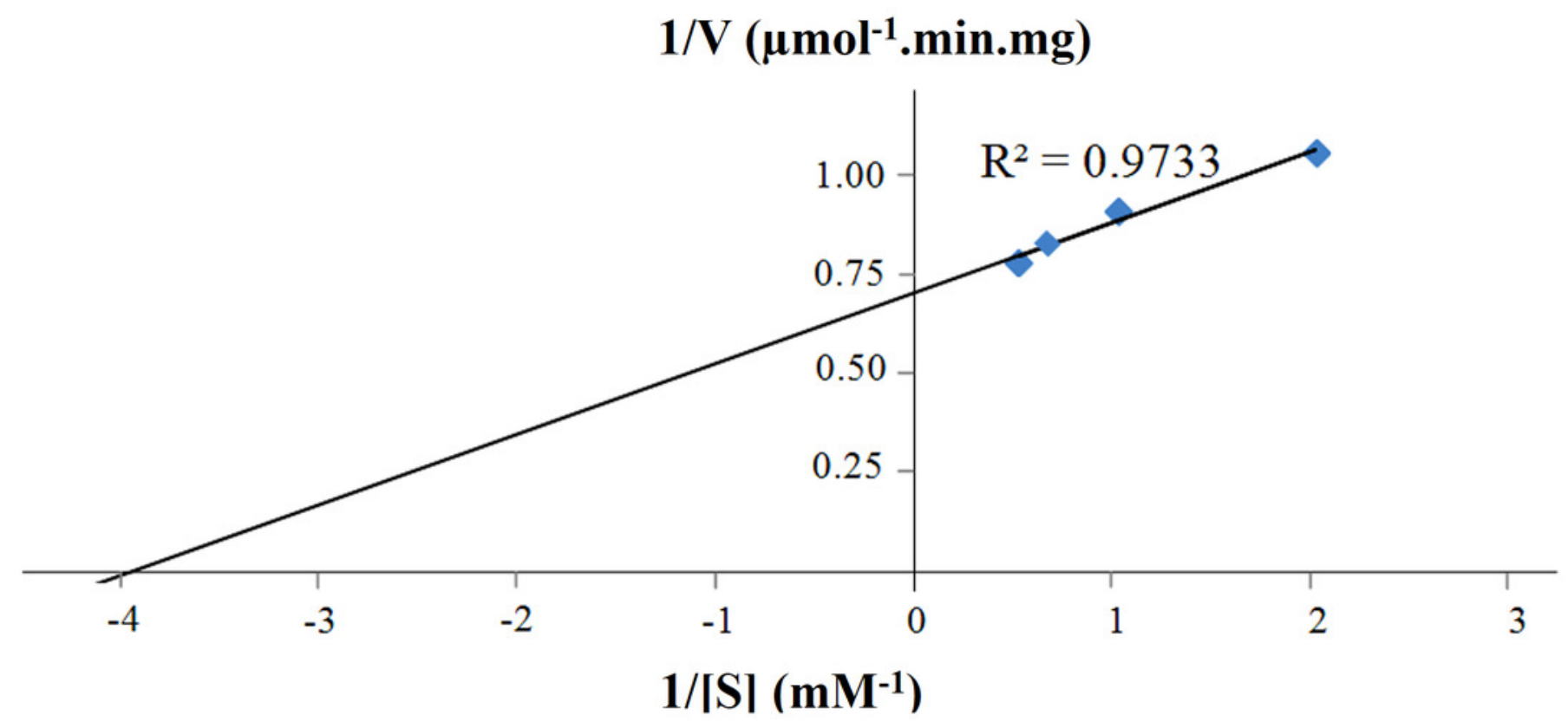




\section{Figure 7}

Effect of metal-ions ( $1 \mathrm{mM}$ and $10 \mathrm{mM}$ ), ethylenediaminetetraacetic acid (EDTA) (1 mM and $10 \mathrm{mM}$ ) and urea ( $0.1 \mathrm{M}$ and $1.0 \mathrm{M})$ on the activity of CbhB.

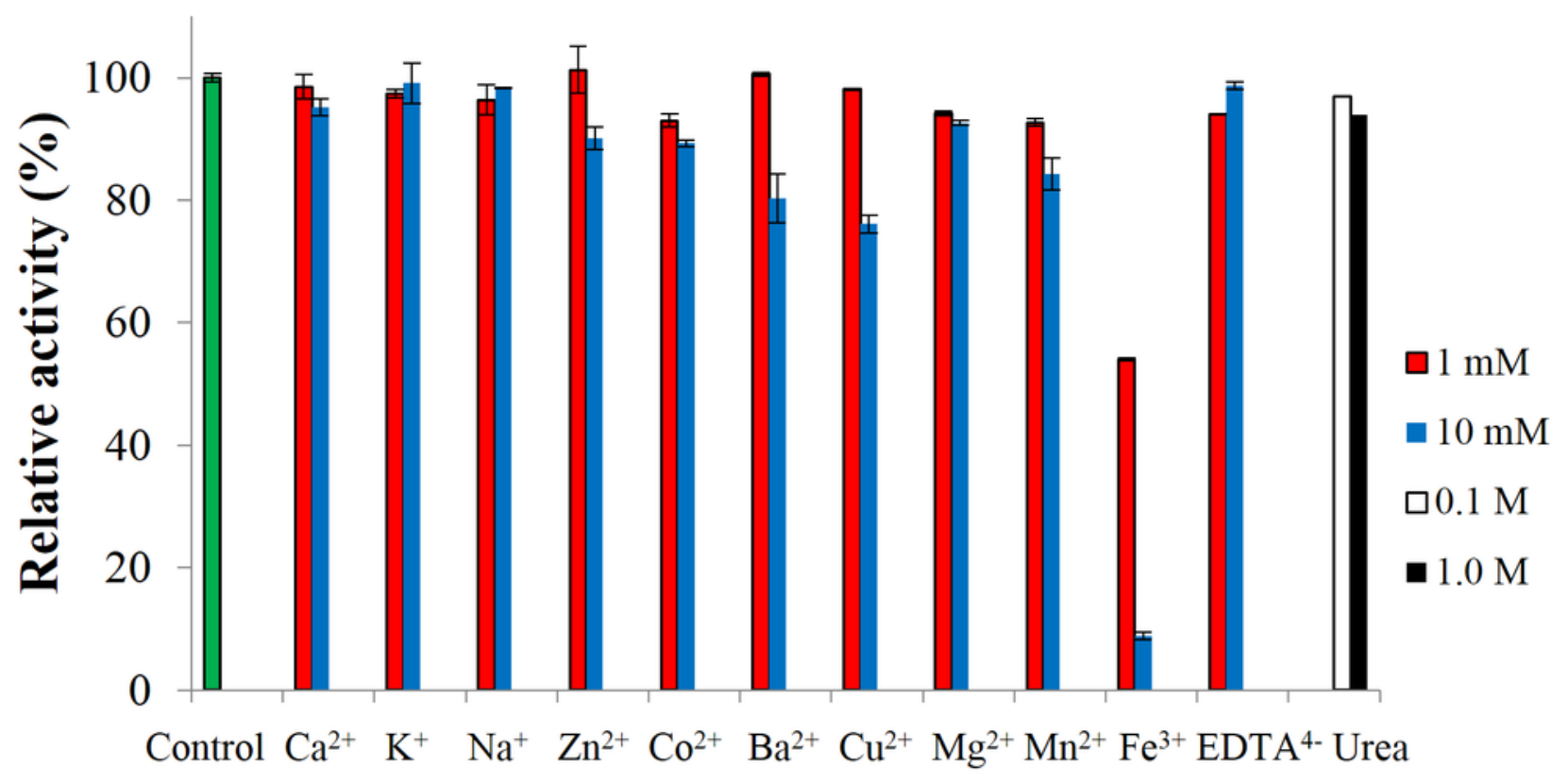


Figure 8

Response surface diagrams of oil palm empty fruit bunch (OPEFB) hydrolyses using various loadings of Cellic ${ }^{\circledR}$ CTec2 (5.5-25\%) and CBHB (0.1-0.5\%).

Production of reducing sugars was measured using DNS assays (Section 2.5). The contour lines are the two dimensional representation of the response surface. All points within the same contour line have equal reducing sugar concentration.

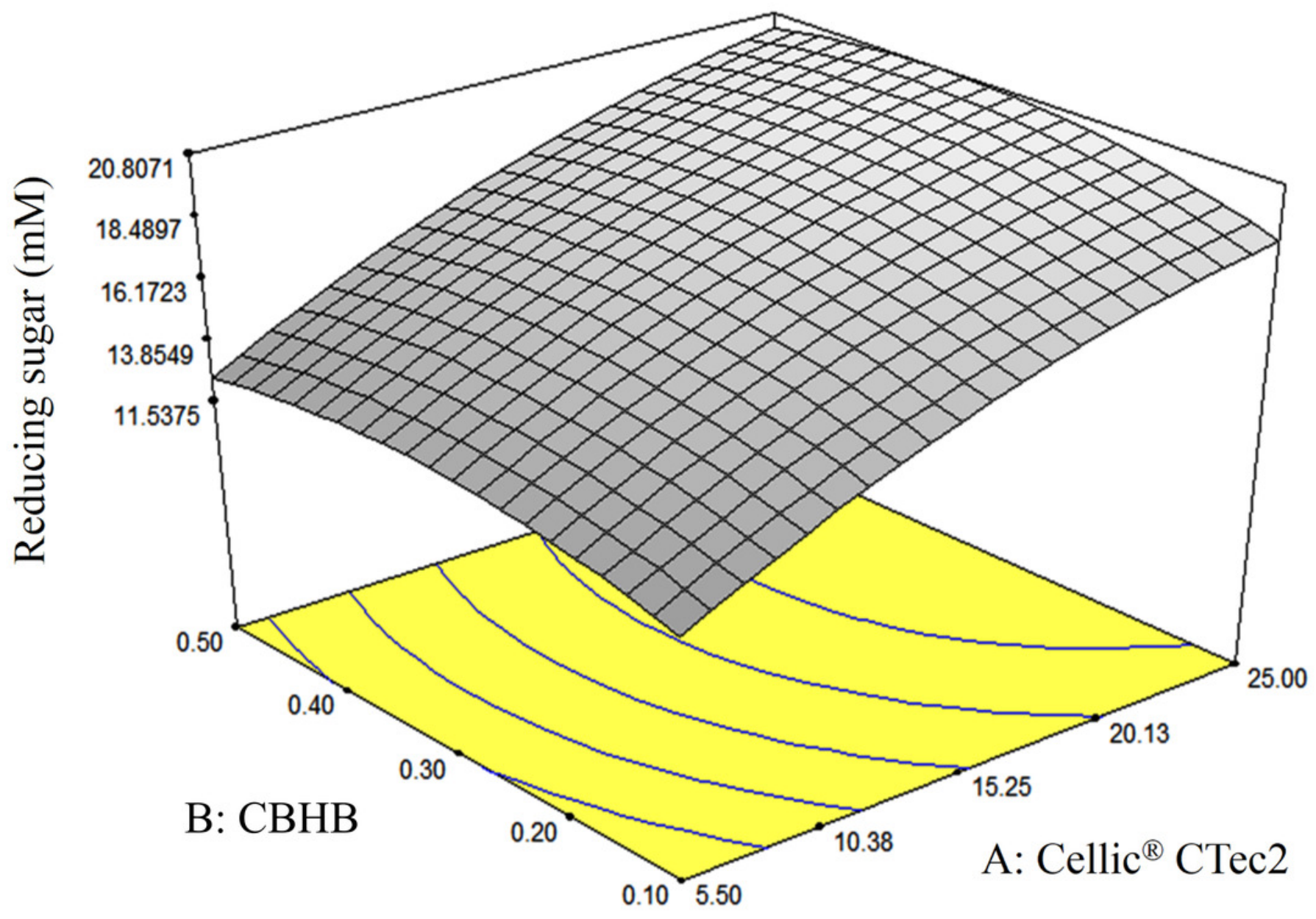


Figure 9

ATR-FTIR spectra of OPEFB treated with Cellic ${ }^{\circledR}$ CTec2 and Cellic ${ }^{\circledR}$ CTec2 supplemented with CbhB

Dried OPEFB samples were scanned from wavenumber of 650 to $4,000 \mathrm{~cm}^{-1}$ using a Perkin Elmer Spectrum 400 series equipped with Universal ATR sampler accessories.

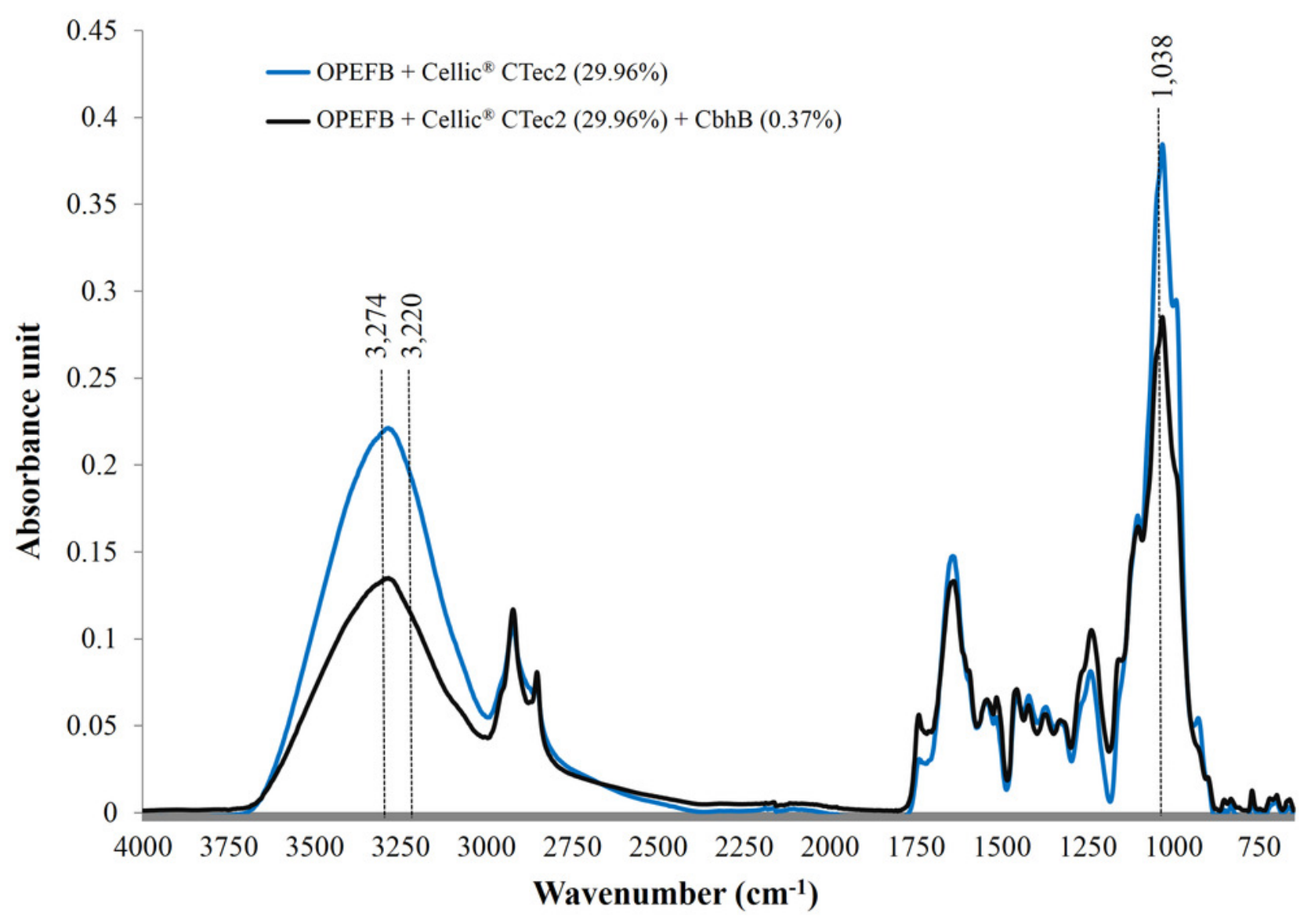

